\title{
THE CORACOCLAVICULAR JOINT AND RELATED PATHOLOGICAL CONDITIONS*
}

\author{
BY \\ W. H. D. DE HAAS, $\uparrow$ M. J. KINGMA,+ AND F. DRUCKER§ \\ Amsterdam
}

According to the theory of the development of the shouldergirdle of Gegenbaur (1898), the embryonic coracoid is connected with the clavicle by the cartilaginous procoracoid. In the course of normal development, this bone becomes fibrous and is ultimately transformed into the coracoclavicular ligaments. On their surface, in normal adults, nests of chondrocytes and even small nodules of cartilage are frequently seen. Whereas Gegenbaur's theory has been accepted by some (including Huntington, 1918; Ravelli, 1955), it has been opposed by others (Hanson, 1920; Hommes, 1921). However, whatever its value from the morphogenetic point of view, this theory can provide a suitable basis for the

$$
1964 \text {. }
$$

* Based on a paper given to the Heberden Society on April 24,

† Outpatients Department of Rheumatology, Wilhelminagasthuis, and Amsterdams Centrum voor Rheumatiekbestrijding.

$\ddagger$ Department of Orthopaedic Surgery.

$\S$ Department of Pathologic Anatomy, Wilhelminagasthuis, University of Amsterdam. understanding of the congenital and acquired abnormalities described in the present paper.

\section{(A) Congenital Abnormalities}

(1) Coracoid Tubercle.-In normal circumstances, the coracoclavicular ligaments arise from the elbow and part of the upper surface of the coracoid process and are inserted into the conoid tubercle and trapezoid line on the clavicle. The conoid tubercle, as a rule no more than a small rough surface elevation, occasionally grows out in the direction of the coracoid process, in which case the term "coracoid tubercle", as proposed by Jaluvka (1956), would appear to be more appropriate. This author has shown how the process then "articulates" with the trapezoid ligament (a situation comparable to the articulation of the odontoid process of the axis with the transverse ligament of the atlas). The clavicular portion of the ligaments has atavistically maintained its bony structure, whereas the coracoid part has remained fibrous (Fig. 1).

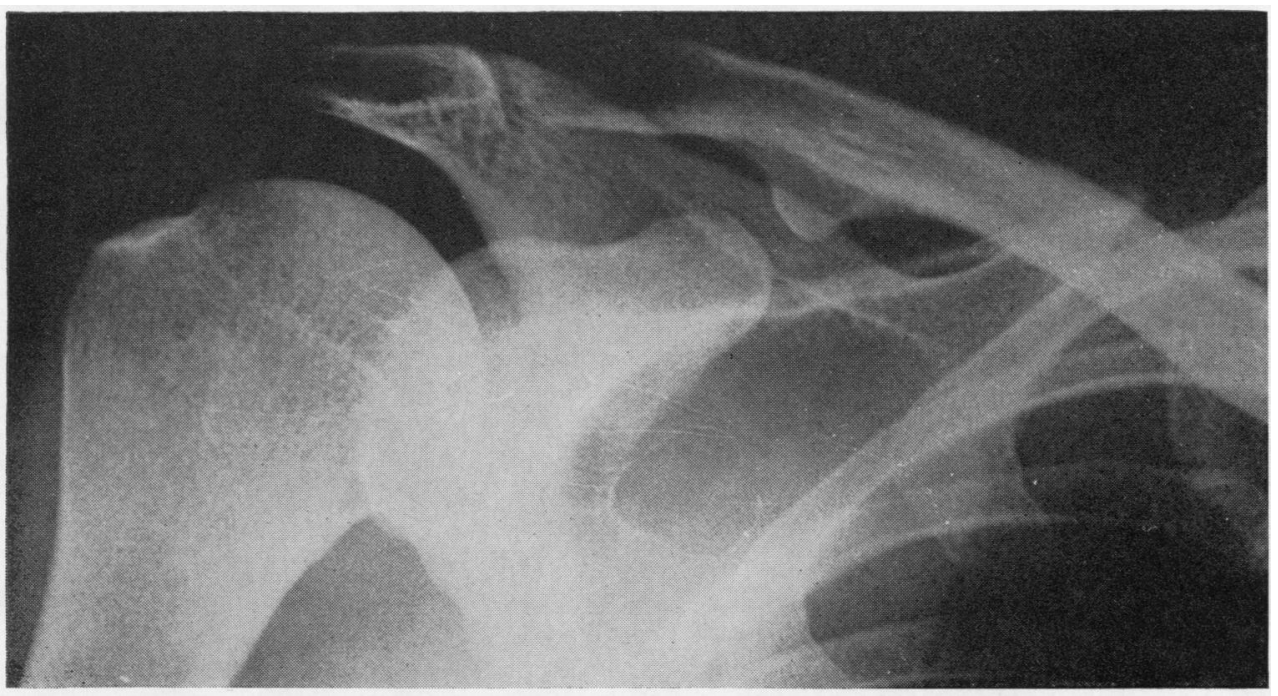

Fig. 1.-Coracoid tubercle on clavicle; no reaction on coracoid process. 
(2) Coracoclavicular Joint.-The coracoid process may, however, react by forming a similar outgrowth. The two processes can then form a real joint, which is surrounded by a capsule and lined by synovium, and the two bony surfaces being covered by cartilage* (Fig. 2).

This condition has interested anatomists (Gruber, 1861; Poirier, 1890; Gowland, 1915, Schlyvitch, 1937; Miessen, 1937, Lewis, 1959) radiologists Pape, 1930; Brailsford, 1944; and Köhler, 1953), while some cases have been described by orthopaedic surgeons (Possati, 1926; Gradoyevitch, 1939; Nutter, 1941; Wertheimer, 1948; Pizon, 1957). Hitherto it has failed to attract the attention of rheumatologists. We have carried out a radiographic investigation of both shoulders in one thousand patients with shoulder complaints, and have found the anomaly in twelve, an incidence of $1 \cdot 2$ per cent. This shows that, far from being rare, the condition is about as common as a cervical rib, which occurs in from 0.5 to 1 per cent. of the population (Haven, 1939; Biemond, 1953; McArdle, 1964), our findings agreeing with those of the few clinicians who have performed similar investigations (Table I). In our small series of 132 children up to 12 years, two cases occurred, which suggests the incidence to be as high in children as in adults.

\footnotetext{
* This kind of articulation has been reported to represent the normal situation in the gorilla and the gibbon (Keith, 1894; Ravelli, 1955). We have been unable to confirm this in the skeletons of the Amsterdam Zoological Gardens, and Dr. Osman Hill, of the London Zoological Gardens, informs us that he too has never seen an example. The claim that Negroes (Frassetto, 1921) or Australian aboriginals (Ray, 1959) are particularly apt to show this anomaly must be likewise rejected.
}

TABLE I

INCIDENCE OF CORACOCLAVICULAR JOINT SEEN IN $X$ RAYS

\begin{tabular}{|c|c|c|c|c|c|c|}
\hline \multirow{2}{*}{ Date } & \multicolumn{3}{|c|}{ Author } & \multirow{2}{*}{$\begin{array}{l}\text { No. of } \\
\text { Cases }\end{array}$} & \multicolumn{2}{|c|}{ Coracoclavicular Joints } \\
\hline & & & & & No. & Per cent. \\
\hline 1941 & Nutter & . & 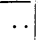 & 1,000 & 12 & $1 \cdot 2$ \\
\hline 1948 & Wertheimer & $\cdot$ & $\cdots$ & 277 & 2 & $0 \cdot 7$ \\
\hline 1959 & Jaluvka & $\cdot$ & $\ldots$ & 1,735 & 24 & $1 \cdot 38$ \\
\hline $\begin{array}{l}1962 \\
1962\end{array}$ & $\begin{array}{l}\text { Present seri } \\
\text { Present serie }\end{array}$ & 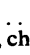 & . & $\begin{array}{r}1,000 \\
132\end{array}$ & $\begin{array}{r}12 \\
2\end{array}$ & $\begin{array}{l}1 \cdot 2 \\
1 \cdot 5\end{array}$ \\
\hline
\end{tabular}

Since all our patients had shoulder pain, they might be expected to show a higher incidence of the condition than that occurring in unselected subjects. In fact, however, the incidence in this series is lower than that reported by anatomists. Jaluvka (1956), in an examination of all collar-bones and shoulderblades in a Czech graveyard, found an incidence of up to 6.4 per cent. (Table II). This discrepancy

TABLE II

INCIDENCE OBSERVED ANATOMICALLY BY JALUVKA (1956)

\begin{tabular}{|c|c|c|c|c|}
\hline \multirow{2}{*}{\multicolumn{2}{|c|}{ Anomaly }} & \multirow{2}{*}{ Total No. } & \multicolumn{2}{|c|}{$\begin{array}{l}\text { Incidence of Anomalies } \\
\text { (per cent.) }\end{array}$} \\
\hline & & & Right & Left \\
\hline $\begin{array}{l}\text { Clavicular } \\
\text { Coracoid }\end{array}$ & & $\begin{array}{l}491 \\
457\end{array}$ & $\begin{array}{l}6 \cdot 4 \\
0 \cdot 7\end{array}$ & $\begin{array}{l}3 \cdot 8 \\
0 \cdot 2\end{array}$ \\
\hline
\end{tabular}

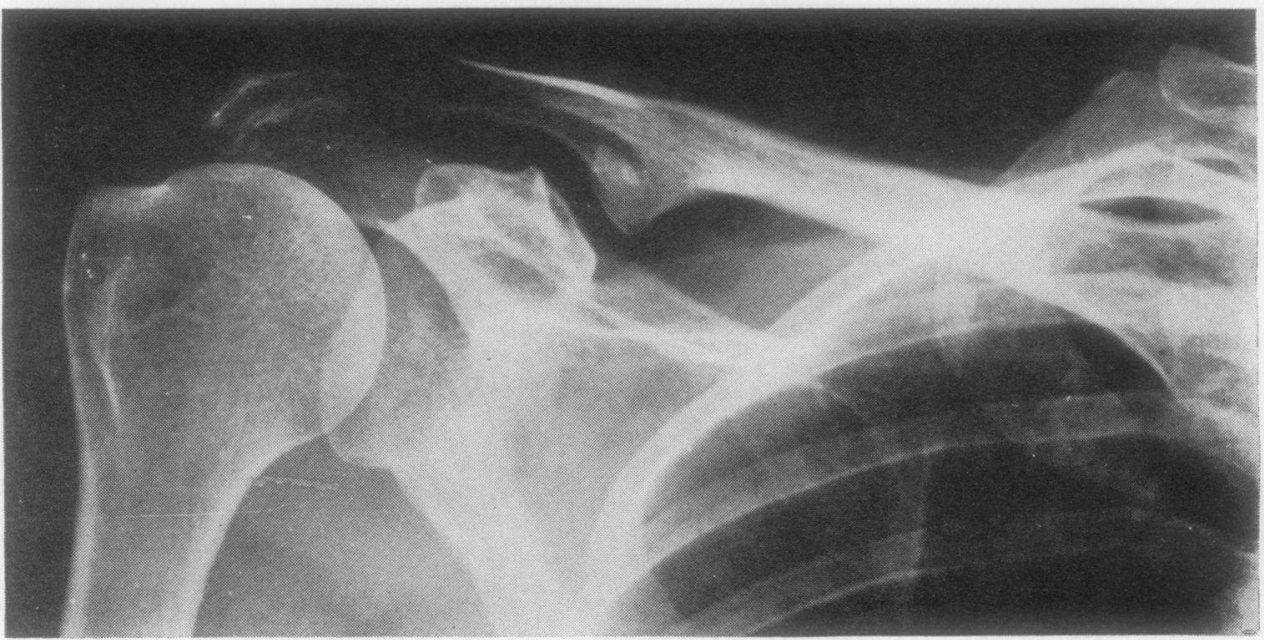

Fig. 2.-Coracoid articulation, showing articular facet on both clavicle and coracoid process. 
can be readily explained by the fact that the articulating processes frequently consist of cartilage (apparently in 80 per cent. of cases), which fails to show on $x$-ray film. In addition, the articular facets may be completely level with the bones.

In our series a coracoclavicular joint was considered to be present if the conoid tubercle stood out at least $5 \mathrm{~mm}$. below the general level of the clavicle or if a flattening of its inferior outline suggested the presence of an articular surface (Fig. 2). Indeterminate types were occasionally seen.

Some particulars of our twelve patients are analysed in Table III. Nine of the patients were men, and three were women, whereas the overall ratio between men and women in our out-patients' department is nine men to eleven women.

In six patients the articulation occurred on the left side and in four on the right side, irrespective of right- or left-handedness. In two cases it was bilateral.

There was no association with accompanying disease of the shouldergirdle.

Our series does not support the view, held by some authors (Lane, 1888; Jaluvka, 1956), that the anomaly results from heavy manual labour (Table III). We found it in children as well as adults, and some authors report associated abnormalities of the lateral part of the clavicle, which suggests a congenital origin (Gowland, 1915; Hall, 1950).
The large family tree shown in Fig. 3 gives strong support to the idea that the condition may be inherited:

(1) It occurred in both male and female members of this large family over three generations.

(2) In the second generation, consisting of ten children, seven members ( 70 per cent.) were affected; in the third generation, numbering 34 grandchildren, nine ( 26 per cent.) were affected. The percentage of affected children of affected parents in Generation II is $\mathbf{3 2}$ per cent.

(3) It was transmitted by both men and women.

(4) The offspring of unaffected members failed to show the anomaly.

It would therefore appear that the trait is transmitted as an autosomal dominant, with a varying degree of expressivity.

In only two other much smaller families, were we able to radiograph all members of three generations. Though the heredity was clear, the degree of penetration was less.

As a rule there are no symptoms, and the anomaly is discovered only by chance. Occasionally, however, it may give rise to pain in the shoulder, radiating into the arm. This pain is accompanied by paraesthesiae and is aggravated by movement, abduction, rotation, and forward elevation being particularly painful.

TABLE III

CLINICAL PARTICULARS OF TWELVE CASES

\begin{tabular}{|c|c|c|c|c|c|c|c|}
\hline \multirow{2}{*}{ Case No. } & \multirow{2}{*}{ Age (yrs) } & \multirow{2}{*}{ Sex } & \multicolumn{2}{|c|}{ Size (mm.) } & \multirow{2}{*}{ Dominant Hand } & \multirow{2}{*}{ Concomitant Disease } & \multirow{2}{*}{ Occupation } \\
\hline & & & Right & Left & & & \\
\hline $\begin{array}{l}1 \\
2 \\
3 \\
4 \\
5 \\
6 \\
7 \\
8 \\
9\end{array}$ & $\begin{array}{l}64 \\
38 \\
50 \\
62 \\
68 \\
44 \\
59 \\
56 \\
47\end{array}$ & $\begin{array}{l}\mathbf{M} \\
\mathbf{M} \\
\mathbf{M} \\
\mathbf{M} \\
\mathbf{M} \\
\mathbf{M} \\
\mathbf{M} \\
\mathbf{M} \\
\mathbf{M}\end{array}$ & $\begin{array}{l}8 \\
7\end{array}$ & $\begin{array}{r}9 \\
7 \\
8 \\
10 \\
7 \\
5\end{array}$ & $\begin{array}{l}\mathbf{R} \\
\mathbf{R} \\
\mathbf{R} \\
\mathbf{R} \\
\mathbf{R} \text {, later } \mathbf{L} \\
\mathbf{R} \\
\mathbf{R} \\
\mathbf{R} \\
\mathbf{R}\end{array}$ & $\begin{array}{l}\text { None } \\
\text { None } \\
\text { Arthrosis C5-7 } \\
\text { None } \\
\text { None } \\
\text { None } \\
\text { Arthrosis C5-6 } \\
\text { Arthrosis C5-6 } \\
\text { None }\end{array}$ & $\begin{array}{l}\text { Clerk } \\
\text { Barber } \\
\text { Barber } \\
\text { Postman } \\
\text { Pilot } \\
\text { Clerk } \\
\text { Cigar-maker } \\
\text { Greengrocer } \\
\text { Surveyor }\end{array}$ \\
\hline $\begin{array}{l}10 \\
11\end{array}$ & $\begin{array}{l}56 \\
68\end{array}$ & $\begin{array}{l}\mathrm{F} \\
\mathrm{F}\end{array}$ & $\begin{array}{l}5 \\
7\end{array}$ & 5 & $\begin{array}{l}\mathbf{R} \\
\mathbf{R}\end{array}$ & $\begin{array}{l}\text { None } \\
\text { Acromioclavicular } \\
\text { arthrosis }\end{array}$ & $\begin{array}{l}\text { Housewife } \\
\text { Housewife }\end{array}$ \\
\hline 12 & 39 & F & & 8 & $\mathbf{L}$ & None & Housewife \\
\hline
\end{tabular}

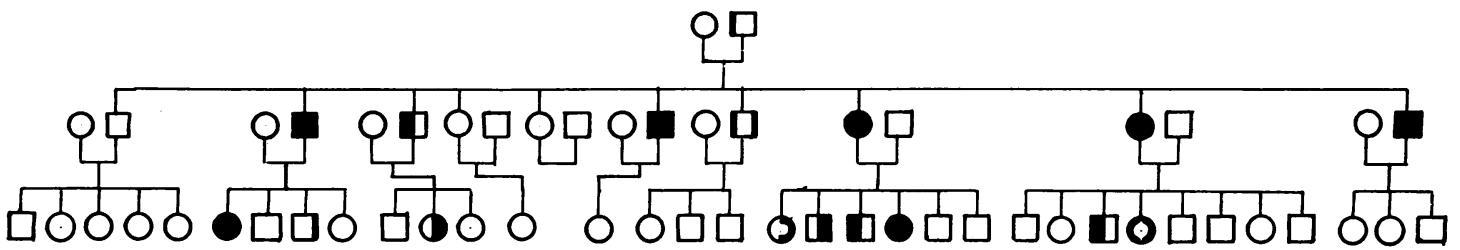

Fig. 3.-Family tree showing affected children and grandchildren. The amount of black shown for each person affected corresponds with the size of the tubercles. The side (right, left, or bilateral) is also indicated. 
A useful procedure to determine whether or not the pain arises from the coracoclavicular joint is an injection of novocaine, which produces immediate relief. Repeated injections, especially in combination with hydrocortisone, will often lead to permanent relief.

The two following anomalous conditions of the clavicle are often associated with abnormal connexions of this bone with the coracoid process.

(3) Clavicular Defects.-Rarely in man, the acromial third of the clavicle is lacking, a situation which is normal in such animals as the three-toed sloth and the cassowary. The remaining sternal part then maintains a close connexion with the coracoid process, from which it originates, according to Gegenbaur's theory. There is either a strong fibrous band reinforcing the normal coracoclavicular ligaments, or these ligaments are transformed into a coracoclavicular joint. Such cases in man are probably instances of manifest or latent cleidocranial dysostosis (La Chapelle, 1918; Hohmann, 1958).

(4) Bifurcate Clavicle.-Still rarer is the opposite situation, in which the acromial extremity of the clavicle has widened. Encroaching upon the territory of the scapula and the coracoid process it may likewise articulate with the latter (Bennett, 1873).*

\section{(B) Acquired Abnormalities}

(1) Acquired Disease in the Coracoclavicular Joint There is reason to suppose that rheumatoid arthritis may involve this articulation.

* Henschen (1938) has proposed very similar terms for this condition and for the anomaly described here under $A$ (1) and (2), i.e. clavicula bifurcata acromialis and clavicula bifurcata supracoracoidea respectively. In our opinion, this denomination wrongly suggests a similar morphogenesis for the two conditions.

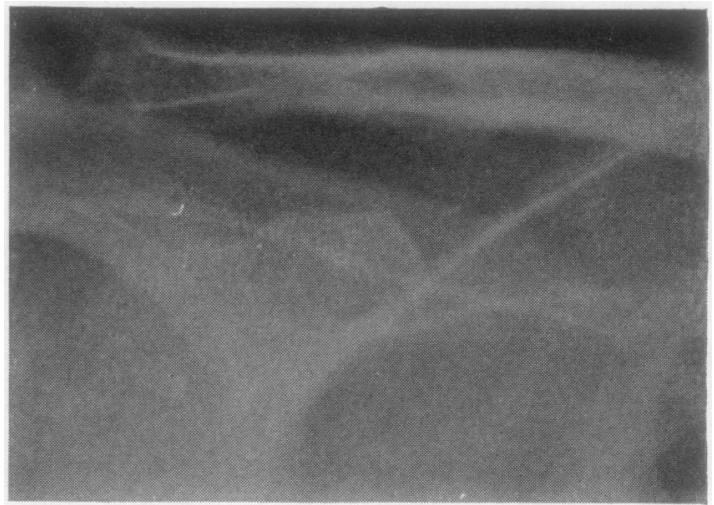

Fig. 4.-Severe rheumatoid arthritis. Acromioclavicular erosions, also probably present on coracoid tubercle.

Fig. 4 shows an $x$ ray from a woman with severe rheumatoid arthritis and large erosions in the acromioclavicular joint.

Erosions can likewise be seen along the outline of the coracoid tubercle, but definite proof that they are caused by the rheumatoid arthritis is lacking.

With regard to osteo-arthrosis the evidence is conclusive. Although there is only one doubtful case of this complication on record (that of Possati, 1926, with considerable traumatic changes), it does not seem to be exceptional, because we have seen four such patients. In addition to the symptoms already mentioned, these patients complained that all movements were accompanied by painful crepitus, which could be easily located at the site of the joint. They derived benefit from injections of a local anaesthetic, but the discomfort experienced by one patient (Fig. 5) was severe enough to necessitate removal of the entire joint. This operation has

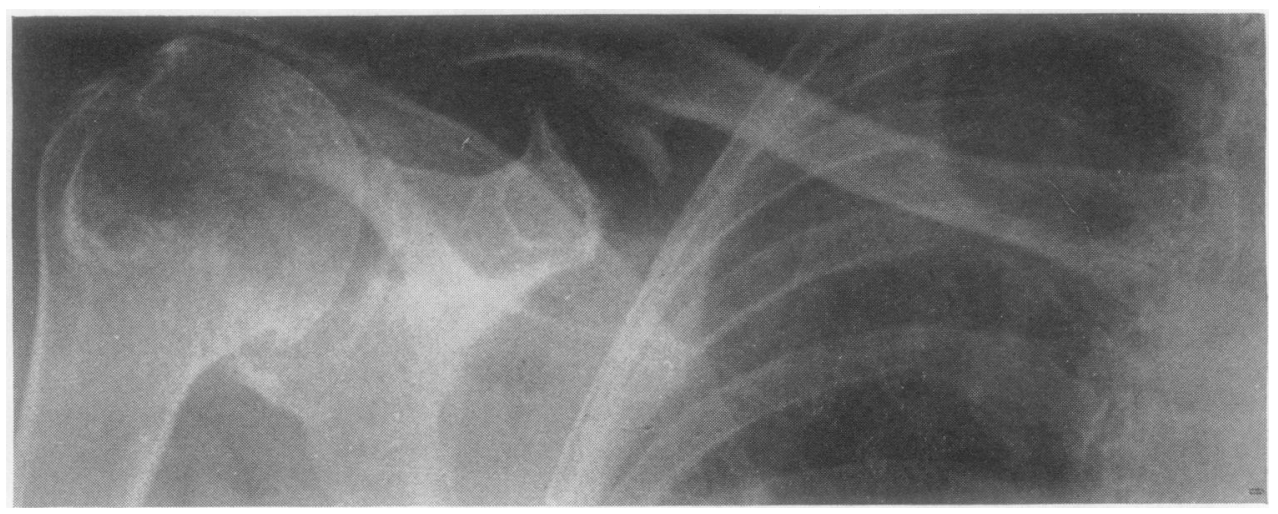

Fig. 5.-Coracoclavicular joint, showing marginal lipping. Osteo-arthrosis verified at operation. 
previously been performed by Wertheimer (1948), del Valle and Giordano (1943), and Hall (1950), in cases not complicated by osteo-arthrosis.

At operation the articular facets were seen to be covered by irregular cartilage, which on microscopic examination looked frayed with colonies of swollen chondrocytes. There was extensive marginal lipping. In several places the synovial lining remained clearly discernible (Figs 6 and 7; Figs 8-10, overleaf). In sagittal sections the fibrous tissue of the conoid and trapezoid ligaments could be distinctly recognized merging into the articular structures.

Fig. 6.-Specimen (measuring $4 \frac{1}{2} \mathrm{~cm}$.) obtained at operation.

Left: clavicular facet with ligaments attached.

Right: coracoid facet. Irregular cartilage.
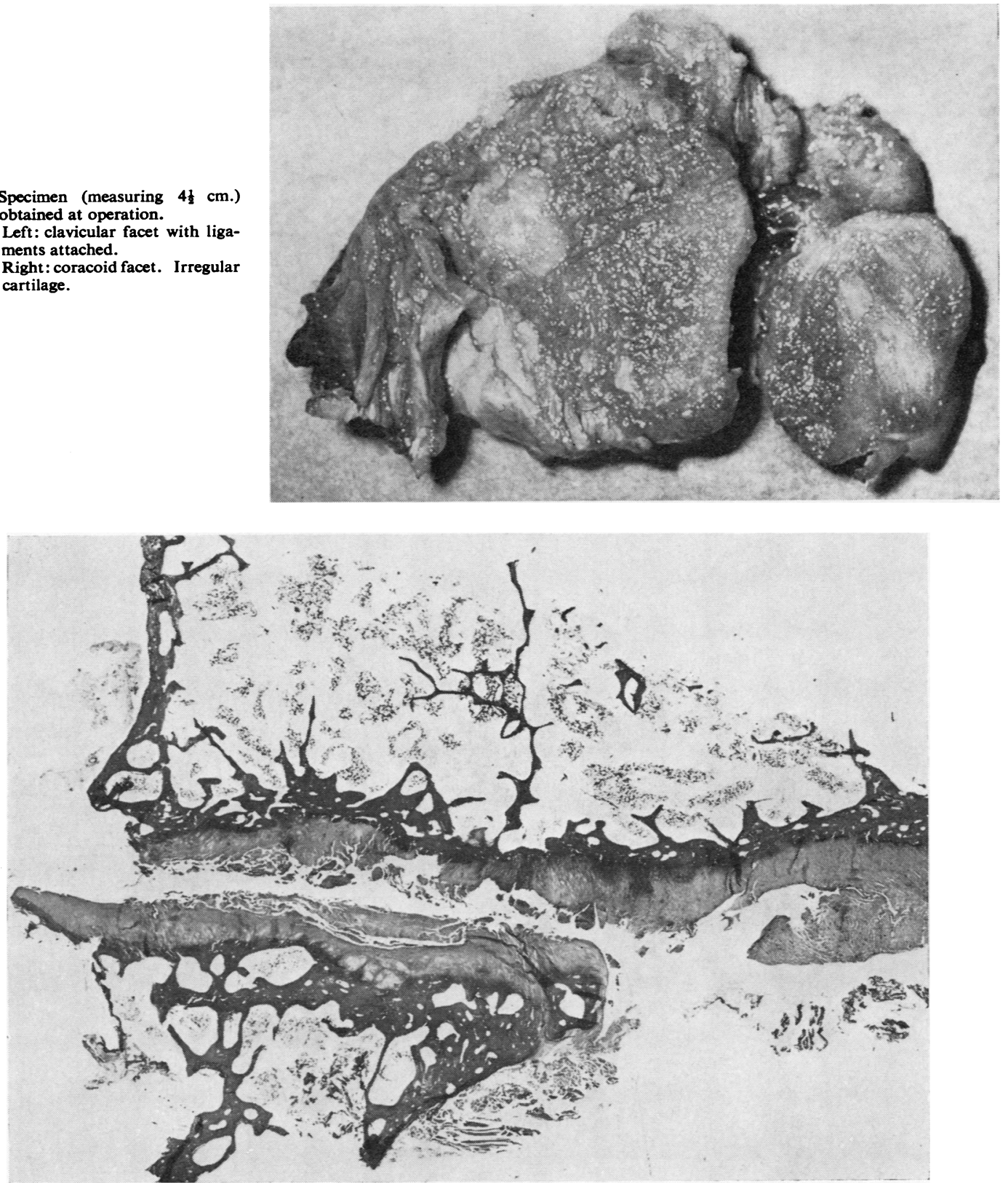

Fig. 7.-Sagittal section of cartilage showing marginal lipping. $\quad \times \mathbf{4} \cdot \mathbf{2}$. 


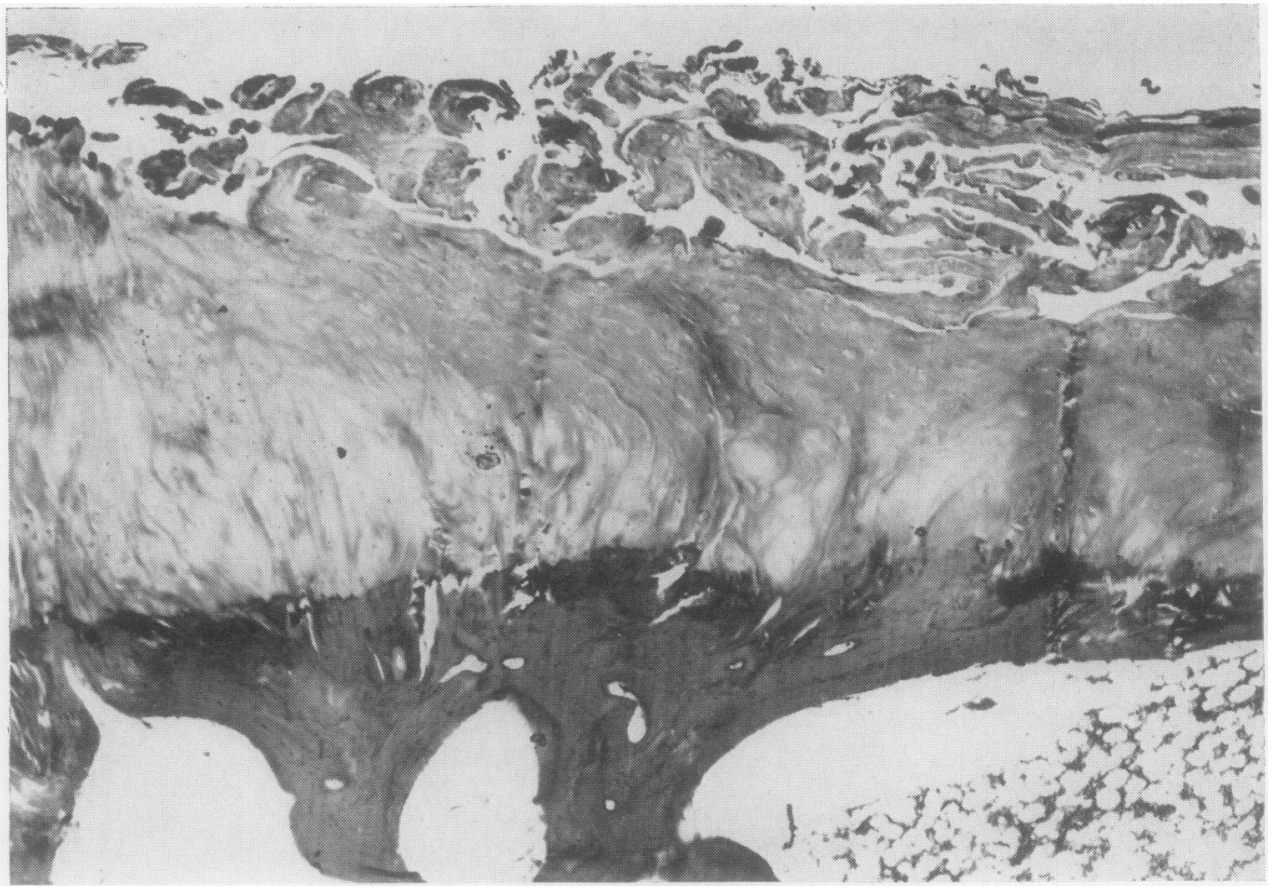

Fig. 8.-Articular cartilage. Higher magnification. $\times 36$.

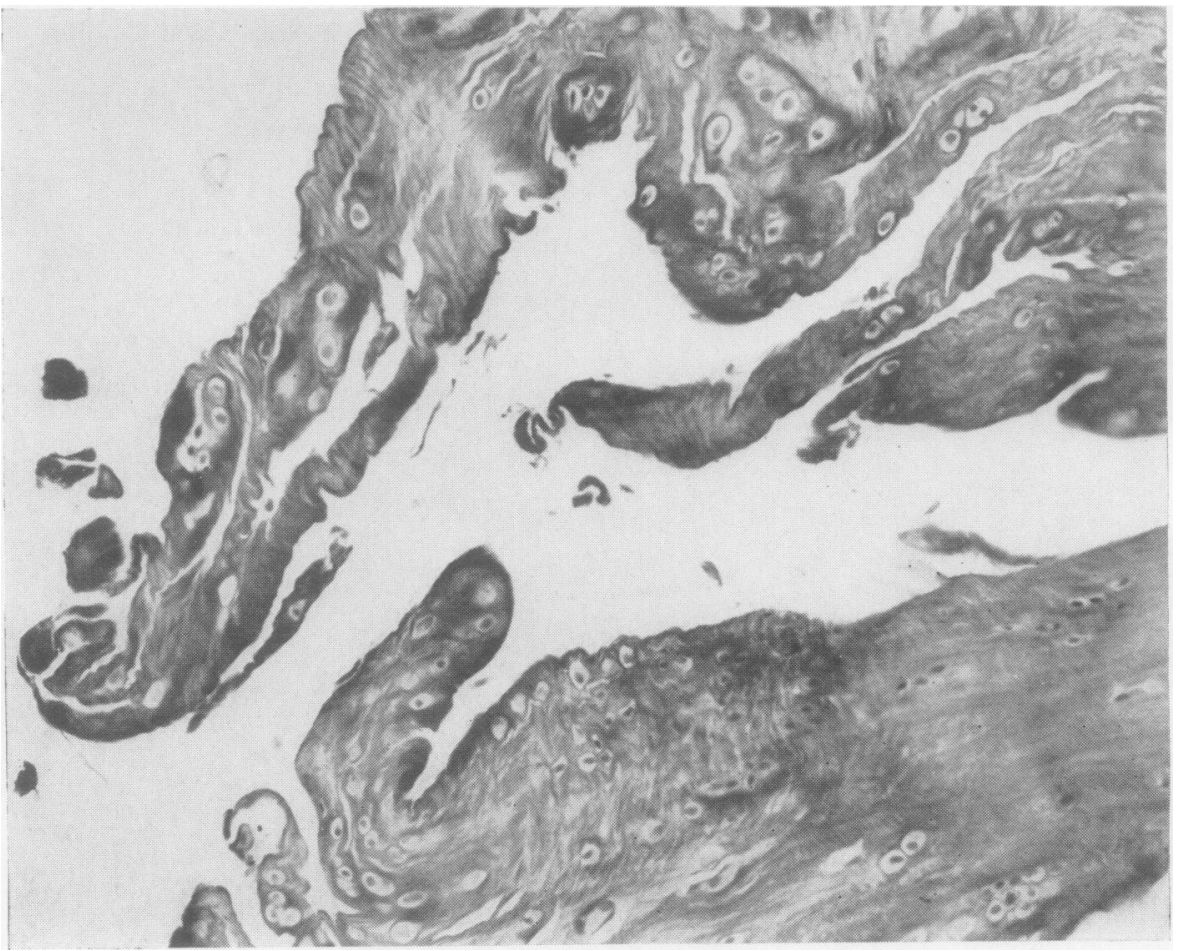

Fig. 9. - Cartilage much frayed with swollen chondrocytes. $\times 400$. 


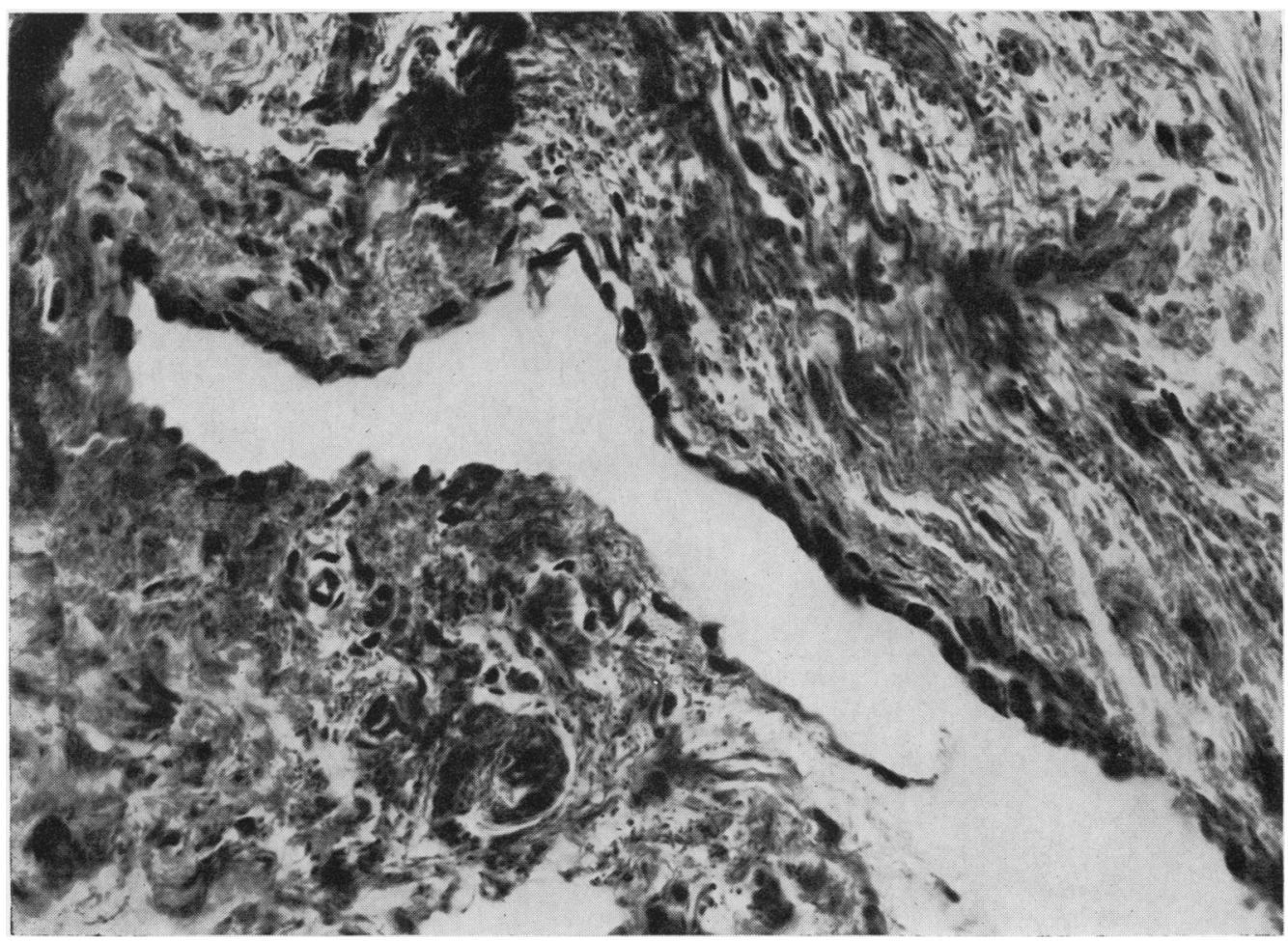

Fig. 10.-Synovial lining, locally preserved. $\times 400$.

(2) Calcification and Ossification in Intact Ligaments.-Faint calcified streaks in the conoid and trapezoid ligaments are occasionally seen.

(3) Calcification and Ossification in Torn Ligaments. - Complete calcification followed by ossification may occur after the ligaments have been lacerated by trauma, nearly always an acromioclavicular dislocation. Once established, the ossification is permanent (one of our patients had his clavicle subluxated 50 years ago).

The readiness and completeness with which these ligaments ossify, is probably due to their origin from, and their admixture with, cartilage. Soule (1946) stressed the frequency of such calcifications, which developed in fourteen out of his eighteen patients with acromioclavicular dislocation. Svab (1937) found a similar incidence (fifteen out of 22 patients). After approximately 3 weeks an amorphous cloudy shadow appears, and after a few more weeks this becomes outlined in the shape of one or more often of both ligaments, ${ }^{*}$ and assumes a bony structure.

* A third ligament, connecting the coracoid process with the scapula, the coracoacromial ligament, may also calcify.
In a specimen discovered by chance in the Amsterdam Vrolik Anatomical Museum the bone had the thickness and the massive appearance of the clavicle, with which it had grown into one (Fig. 11, overleaf).

In most cases, however, a longitudinal striation, indicating the fibres of the ligaments, remains clearly visible in the $x$ ray; the ruptured zone looks frayed; the lateral borders appear somewhat upturned. The disruption nearly always occurs at the coracoid end; although the calcified ligament then remains attached to the clavicle, a small part may remain with the coracoid process (Figs 12 and 13, overleaf). If calcification fails to develop after 8 weeks, it will not do so at a later stage.

This formation, although bearing a superficial likeness to that of the coracoclavicular joint, cannot be confused with it. In spite of its characteristic features and although it is far more common, it is mostly misinterpreted and diagnosed as one of the following conditions.

(4) Calcified Bursitis.-Several bursae have been described near the top of the coracoid process. Gruber (1861), in an exhaustive paper, mentions a 


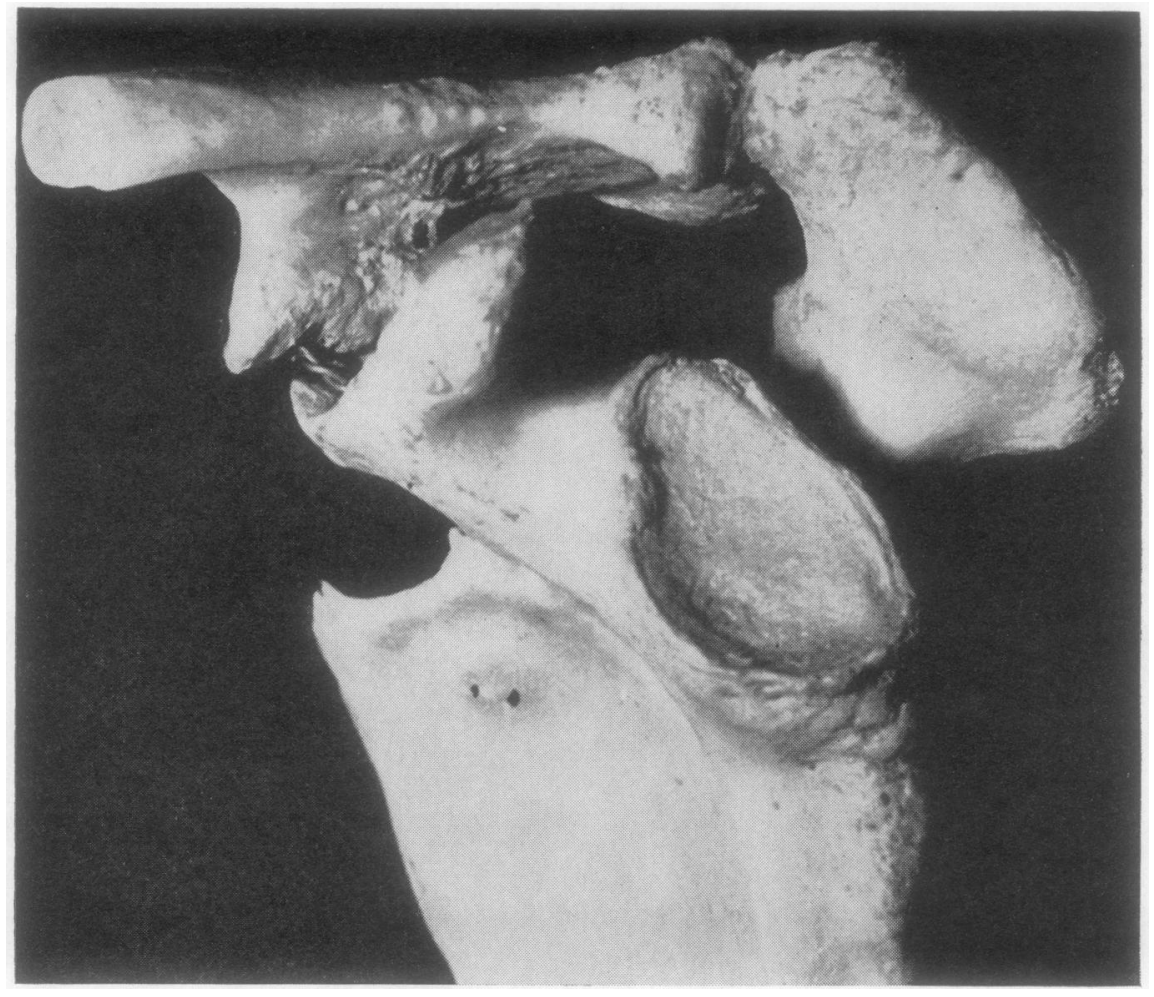

Fig. 11.-Massive ossification of coracoclavicular ligaments.

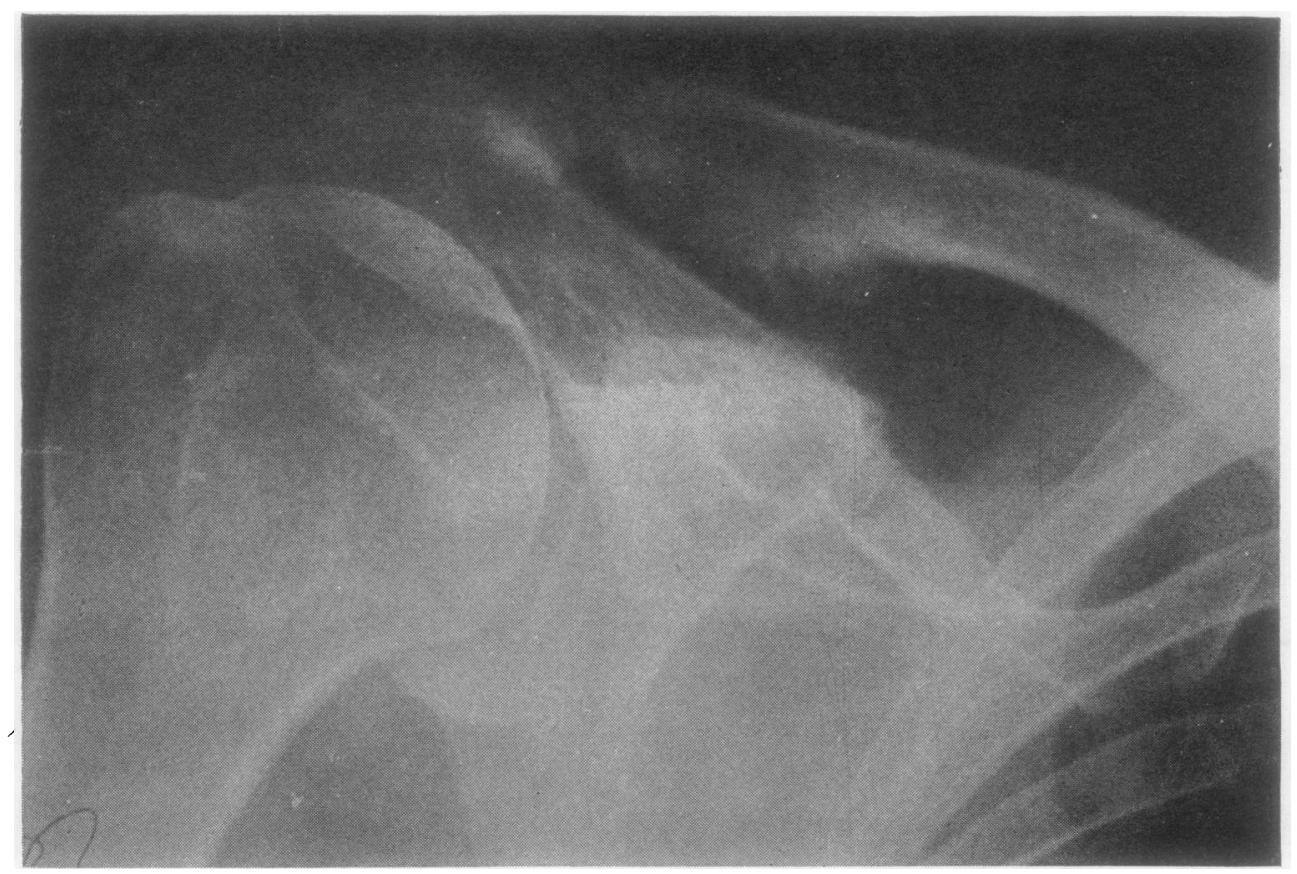

Fig. 12.-Coracoclavicular ligaments torn after acromioclavicular luxation. The larger portion has remained with the clavicle (chiefly the trapezoid ligament). 


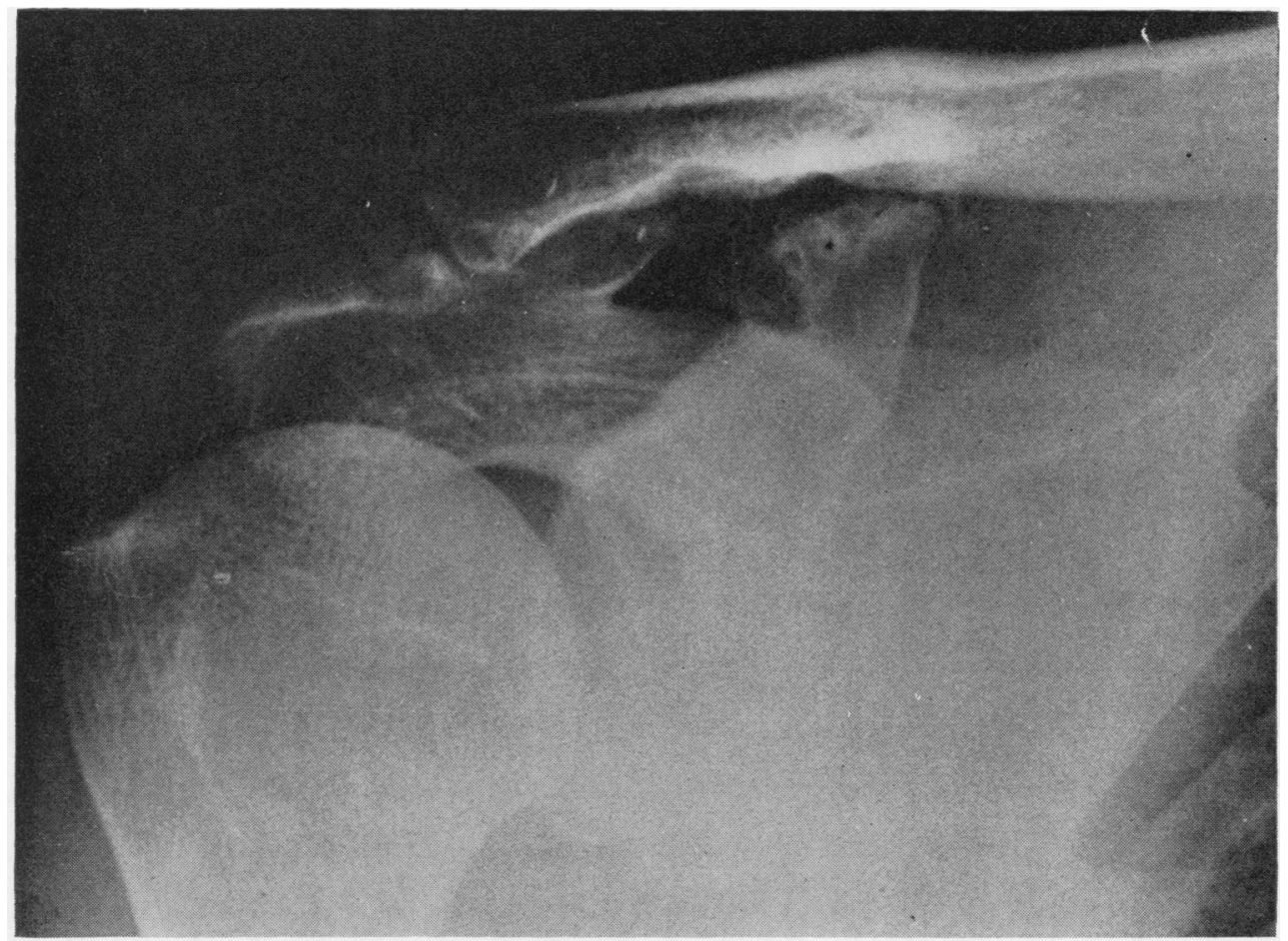

Fig. 13.-Coracoclavicular ligaments disrupted by violent backwards torsion of the right arm. The result is much rarer than that in Fig. 12: nearly the whole of both ligaments has remained with the coracoid process. ( $X$ ray obtained from the Sociale Verzekeringsbank, through the medium of Dr. E. H. La Chappelle.)

medial anterior and posterior, and a lateral anterior and posterior supracoracoid bursa. These occurred in about 30 per cent. of his autopsies. Jaluvka (1957) reports a bursa on the right side in 21.43 per cent., and on the left side in $8 \cdot 2$ per cent.

Calcification of these bursae is very rare (McCurrich, 1938). In the $x$-ray film it shows up as a shapeless cloud between the clavicle and the coracoid process.

(5) Calcified Haematoma.-When calcified a haematoma gives the impression of a structureless shadow, which extends well beyond the territory of the ligaments. It may give rise to a palpable tumour, as may a calcified bursitis.

Addendum.-The technique of the injection into the coracoclavicular joint is very simple. Below the lateral and middle third of the clavicle, just medial to the head of the humerus, the coracoid process can often be seen and it can always be felt. Above it the lower margin of the clavicle can be palpated. A needle inserted perpendicularly between these two points will enter the joint space at a depth of about $2 \cdot 5 \mathrm{~cm}$.

\section{Summary}

The coracoclavicular ligaments are a remnant of the embryonic cartilaginous procoracoid. In about
6 per cent. of normal individuals both extremities of the procoracoid remain cartilaginous.

The procoracoid may also become ossified. If its clavicular portion undergoes this transformation, it gives rise to the development of a coracoid tubercle situated on the clavicle. If, on the other hand, its lower portion also becomes ossified, the two processes may form an articulation. On $x$-ray photographs this may be seen in $1 \cdot 2$ per cent. of otherwise normal shoulders.

The anomaly has been found to be a heritable trait and to be transmitted as an autosomal dominant.

In order to decide whether complaints of pain or crepitus are due to the presence of this anomalous joint, an injection of novocaine into the joint should be performed.

The articulation may also be involved by rheumatoid arthritis and osteo-arthrosis.

Treatment consists in intra-articular injections, but excision of the joint may occasionally become necessary. If normal ligaments are ruptured, they may become calcified or ossified, and the $x$-ray picture may remotely resemble that of a coracoclavicular articulation.

We are much indebted to Dr. J. T. Scott for reading 
the English manuscript, and to Miss L. Huisings, radiographer, for her invaluable technical assistance.

\section{REFERENCES}

Bennett, E. H. (1873). Dublin J. med. Sci., 56, 413.

Biemond, A. (1953). "Ruggemergs- en perifere zenuwziekten", p. 315 . Wetenschappelijke Uitgeverij, Amsterdam.

Brailsford, J. F. (1944). "The Radiology of Bones and Joints", 3rd ed., p. 63. Churchill, London.

Frassetto, F. (1921). Chir. Organi Mov., 5, 116.

Gegenbaur, C. (1898). "Vergleichende Anatomie der Wirbelthiere", vol. 1, p. 494. Engelmann, Leipzig.

Gowland, W. P. (1915). J. Anat. Physiol. (Lond.), 49, 187.

Gradoyevitch, B. (1939). J. Bone Jt Surg., 21, 918.

Gruber, W. (1861). Mém. Acad. Sci. St. Petersbourg, 7 th series, 3 , no. 11 .

Hall, F. J. S. (1950). Brit. med. J., 1, 766.

Hanson, F. B. (1920). Anat. Rec., 19, 309, 327.

Haven, H. (1939). Yale J. Biol. Med., 11, 443.

Henschen, C. (1938). Schweiz. med. Wschr., 19, 535.

Hohmann, G. (1958). "Handbuch der Orthopaedie", vol. 2, p. 956. Thieme, Stuttgart.

Hommes, J. H. (1921). "Over de ontwikkeling van de clavicula en het sternum van vogels en zoogdieren". Dissertatie, Groningen.

Huntington, G. S. (1918). Anat. Rec., 14, 359.

Jaluvka, V. (1956). Cs. Morfol., 4, 99.

(1957). Scr. med. Fac. Med. Brun., 30, 221.

(1959). Čs. Rentgenol., 13, 176.

Keith, A. (1894). J. Anat. Physiol. (Lond.), 22, 593.

Köhler, A. (1953). "Grenzen des Normale und Anfange des pathologischen im Röntgenbilde", p. 155. Thieme, Liepzig.

La Chapelle, E. H. (1918). “Dysostose cleidocranienne héréditaire". Dissertatie, Amsterdam.

Lane, W. A. (1888). J. Anat. Physiol. (Lond.), 22, 593.

Lewis, O. J. (1959). J. Anat. (Lond.), 93, 296.

McArdle, M. J. (1964). In "Textbook of the Rheumatic Diseases”, ed. W. S. C. Copeman, 3rd ed., p. 457. Livingstone, Edinburgh.

McCurrich, H. J. (1938). Brit. J. Surg., 26, 329.

Miessen, E. (1937). Anat. Anz., 83, 392.

Nutter, P. D. (1941). J. Bone Jt Surg., 23, 177.

Pape, R. (1930). Fortschr. Röntgenstr., 42, 127.

Pizon, P. (1957). Presse méd., 65, 982.

Poirier, P. (1890). J. Anat. (Paris), 26, 81.

Possati, A. (1926). Chir. Organi Mov., 10, 533.

Ravelli, A. (1955). Z. Anat. Entwickl.-Gesch., 118, 343.

Ray, L. J. (1959). J. Bone Jt Surg., 41-B, 180.

Schlyvitch, B. (1937). Anat. Anz., 85, 89.

Soule, A. B. (1946). Amer. J. Roentgenol., 56, 607.

Svab, V. (1937). Fortschr. Röntgenstr., 55, 607.

Valle, D. del, and Giordano, A. (1943). Rev. argent.norteamer. Cien. Med., 1, 687.

Wertheimer, L. G. (1948). J. Bone Jt Surg., 30-A, 570.

Discussion.-Prof. E. G. L. Bywaters (Taplow): I should like to ask about the patients who have symptoms. Is the pain referred down the arm or referred directly to the area on abduction of the arm, and can the syndrome be diagnosed without $x$ rays?
DR. DE HAAS: The distribution of the pain is rather vague, but it is usually possible to find local tenderness at the joint; the pain is relieved by local injection of anaesthetic.

Dr. H. WyKeham Balme (London): Are there any difficulties with the radiographic technique?

DR. DE HAAS: One has to be careful to show up the space between the coracoid and the clavicle, but otherwise it is not difficult.

\section{L'articulation coraco-claviculaire et les conditions pathologiques associées \\ RÉSUMÉ}

Les ligaments coraco-claviculaires sont des vestiges du procoracoïde cartilagineux embryonnaire. Chez 6 pour cent env. des sujets normaux les deux extrémités du procoracoïde demeurent cartilagineuses.

Le procoracoïde peut aussi s'ossifier. Quand sa portion claviculaire subit cette transformation, il se forme un tubercule sur la clavicule. Si, d'autre part, sa portion inferieure s'ossifie, les deux apophyses peuvent former une articulation. On peut l'observer en 1,2 pour cent des radiographies des épaules autrement normales.

On a trouvé que cette anomalie est héréditaire et se transmet comme un trait dominant autosome.

Pour décider si une douleur ou une crépitation est due à la présence de cette articulation anormale, on doit procéder à une injection intra-articulaire de novocaïne.

L'articulation peut aussi être affectée par l'arthrite rhumatismale et par l'ostéo-arthrose.

Le traitement consiste en injections intra-articulaires, mais quelquefois l'excision de l'articulation peut être nécessaire.

Lorsqu'on déchire les ligaments normaux, ils peuvent se calcifier ou ossifier et l'image radiologique peut ressembler vaguement à une articulation coraco-claviculaire.

\section{La articulación coraco-clavicular y las condiciones patológicas asociadas}

\section{SUMARIO}

Los ligamentos coraco-claviculares son vestigios del procoracoide cartilaginoso embrionario. En cerca de un 6 por ciento de las personas normales ambas extremidades del procoracoide permanecen cartilaginosas.

El procoracoide puede también osificarse. Cuando esta transformación afecta la porción clavicular, un tubérculo se desarrolla sobre la clavícula. Cuando, por otra parte, su porción inferior se osifica, lo dos procesos pueden formar una articulación. Esto se puede observar en un 1,2 por ciento de las radiografías de hombros normales.

Se ha observado que esta anomalía es hereditaria y se transmite como un rasgo dominante autosoma.

Para determinar si un dolor o crepitaciones se deben a la presencia de esta articulación anormal, una inyección intra-articular de novocaina es necesaria.

Esta articulación puede tambièn verse implicada en la artritis reumatoide y en la osteo-artrosis.

El tratamiento consiste en inyecciones intra-articulares, pero a veces la excisión de la articulación puede ser necesaria.

Cuando hay rotura de los ligamentos normales, estos pueden calcificarse u osificarse y el cuadro radiológico puede sugerir remotamente una articulación coracoclavicular. 